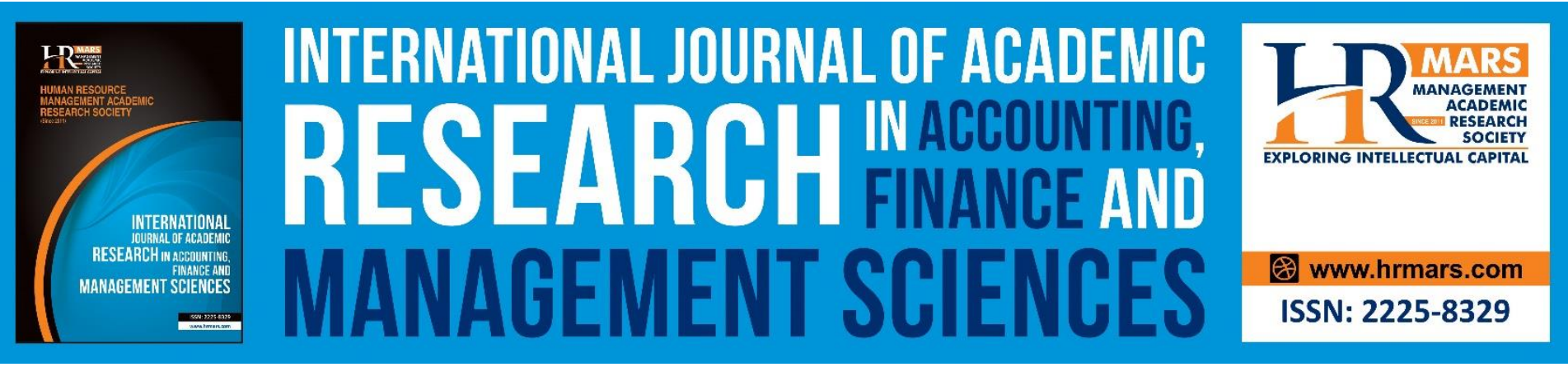

\title{
How is the International Financial Reporting Standards Adjudged? Assessing the Macroeconomic and Financial Market Development Factors Effects for African Evidence
}

\author{
Benjamin Yeboah, Thomas Adomah-Worae, Samuel Addo-Paintsil, and \\ Angelina Brefo
}

To Link this Article: http://dx.doi.org/10.6007/IJARAFMS/v11-i1/8463

DOI:10.6007/IJARAFMS /v11-i1/8463

Received: 23 December 2020, Revised: 21 January 2021, Accepted: 13 February 2021

Published Online: 26 February 2021

In-Text Citation: (Yeboah et al., 2021)

To Cite this Article: Yeboah, B., Adomah-Worae, T., Addo-Paintsil, S., \& Brefo, A. (2021). How is the International Financial Reporting Standards Adjudged? Assessing the Macroeconomic and Financial Market Development Factors Effects for African Evidence. International Journal of Academic Research in Accounting Finance and Management Sciences, 11(1), 1-19.

Copyright: (c) 2021 The Author(s)

Published by Human Resource Management Academic Research Society (www.hrmars.com)

This article is published under the Creative Commons Attribution (CC BY 4.0) license. Anyone may reproduce, distribute, translate and create derivative works of this article (for both commercial and non-commercial purposes), subject to full attribution to the original publication and authors. The full terms of this license may be seen

at: http://creativecommons.org/licences/by/4.0/legalcode

Vol. 11, No. 1, 2021, Pg. 1 - 19

http://hrmars.com/index.php/pages/detail/IJARAFMS

JOURNAL HOMEPAGE

Full Terms \& Conditions of access and use can be found at http://hrmars.com/index.php/pages/detail/publication-ethics 


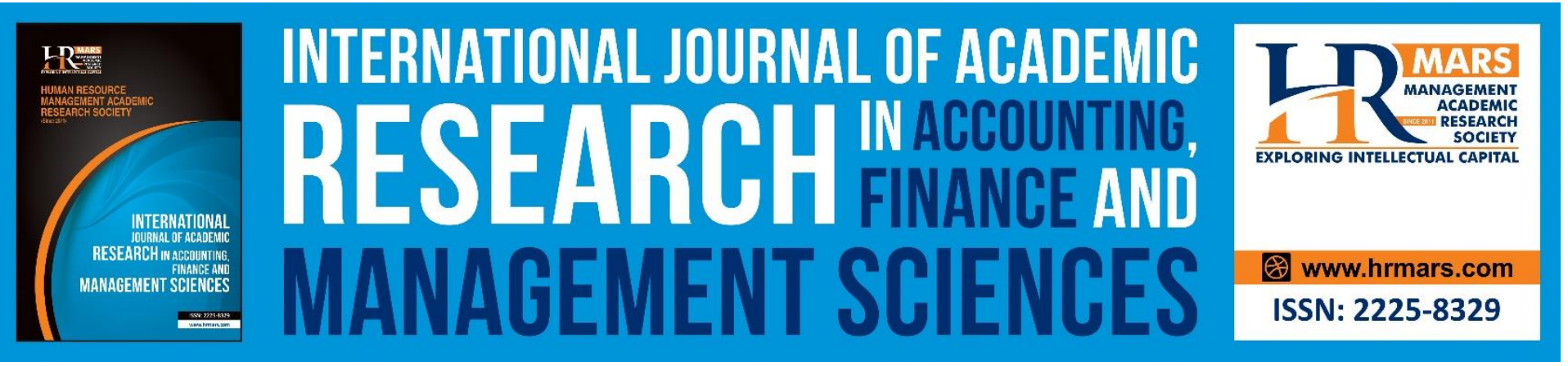

\title{
How is the International Financial Reporting Standards Adjudged? Assessing the Macroeconomic and Financial Market Development Factors Effects for African Evidence
}

\author{
Benjamin Yeboah ${ }^{1}$, Thomas Adomah-Worae ${ }^{1}$, Samuel Addo- \\ Paintsil ${ }^{1}$, and Angelina Brefo ${ }^{2}$ \\ ${ }^{1}$ Kumasi Technical University, Business School, Kumasi City Campus, Ghana \\ 2University of Cape Coast, College of Distance Education, Business School, Ghana \\ Correspondence author:benjabinyeboah@yahoo.com
}

\begin{abstract}
Global continents, especially Europe, have marked the relevancy of International Financial Reporting Standard (IFRS) adoption since its development by the International Accounting Standard Board (IASB). However, a large number of African countries have not adopted it. This study specifically examines the IFRS adopters and non-adopters of African countries which are explained by both macroeconomic and financial market development factors. The study used binary panel logistic regression for estimation of 38 countries using data from the Global Competitiveness Report for 2015/16-2017/18 of African countries to estimate the extent to which macroeconomic and financial market development factors explain the effective adoption of IFRS in Africa. Findings confirm that the tax rate, quality of national accounting body, and rate of inflation do not influence IFRS adoption in African countries. On average, financial market development indicators significantly increase the likelihood of IFRS adoption in African countries. These studies extend support for prior literature about IFRS adoption determinants. The findings highlight the importance and the need for standardsetters to facilitate IFRS adoption of African countries. This study augments the existing strand of empirical literature by looking at macroeconomic and financial market development perspectives.
\end{abstract}

Keywords: IFRS Adoption, Macroeconomic Factors, Financial Market Development Factors, Logistic Regression

\section{Introduction}

Quality macroeconomic factors improve the reliability of the national set of accounting standards because they help in shaping the fundamental basis for the quality of International Financial Reporting Standards (IFRS) within IFRS-based countries (Bonito and Pais, 2018). Macroeconomic factors achieve a sound IFRS adoption that enhances acceptability of financial accounts. It is 
INTERNATIONAL JOURNAL OF ACADEMIC RESEARCH IN ACCOUNTING, FINANCE AND MANAGEMENT SCIENCES

Vol. 11, No. 1, 2021, E-ISSN: 2225-8329 @ 2021 HRMARS

perceived that there is a probability of material misstatement the adoption of IFRS may reveal within the interplay of these factors. Quality macroeconomic factors enhance the soundness of the financial market development of some African countries, consequently having a positive influence on the whole economy, especially on business operations in the country (Bruggermann et al., 2013; Elliot and Elliot, 2013; Shima and Yang, 2012). Some empirical studies pinpoint that major drivers of capital markets are macroeconomic factors. Few studies have established that the interplay of macroeconomic factors and financial market development in explaining the adoption of IFRS (Elliot and Elliot, 2013; Shima and Yang, 2012) in Africa. Generally, the relationships between macroeconomic and financial market development factors have received a minimal attention in accounting research and therefore is much under-researched. It is undoubtedly true that macroeconomic and financial market development factors of nations pass through phases of changes that are difficult to be captured in accounting settings and practices, therefore posing a marked departures on acceptable standards (Albu et al., 2017; Albu et al., 2014). In view of this, the purpose of this paper is to examine how macroeconomic and financial market development factors contribute to explain the adoption of IFRS in Africa.

In Africa, listed firms are expected to adopt and apply IFRS in the harmonization of global acceptability of new standards in the presentation and preparation of consolidated accounts. Bearing in mind the macroeconomic and financial market development factors, there is still a lack of empirical evidence that test the interplay of macroeconomic and financial market development factors on the IFRS adoption in African evidence. Therefore, it becomes very necessary to set the platform for this study. Studies depict that the IFRS adoption ameliorates the situation of quality macroeconomic factors and sound financial market development interplay in strengthening quality accounting information for improving decision making by the users of the accounts (Lawrence, 2013; Beaver et al., 2010). Such interplay is under-research in the African setting. In Africa, the link between macroeconomic factors and financial market development is required to cement the financial reporting environment to cause a reduction in information asymmetry. Giving the insurgence of IFRS adoption's eminent role by the listed firms in Africa, the purpose of this study is to examine the extent of the interplay of macroeconomic and financial market development factors (Othman and Kossentini, 2015) to explain the IFRS adoption. The nature of this study may be scanty from the African context.

Amihud and Mendelson (1986) cited that countries adopting IFRS are more or less assured of quality financial reporting for perceived benefits as lower cost of capital, improving shareholders confidence, increasing liquidity which leads to improving transparency (Shima and Yang, 2012), with consequences of attracting foreign and local investments. Moreso, Barth, Landsman, and Lang, (2008) cited that for comparability and understandability of financial reporting across countries, the IFRS adoption become necessary, as investment across countries, and international trade are encouraged. Barth, Landsman and Lang (2008) argued that IFRS adoption has generally enhanced the financial reporting quality, increase the transparency of financial statements, decrease the cost of capital, increase cross-country investments, and has also enhanced the analyst following.

Several empirical studies have demonstrated that the macroeconomic factors like the legal system, quality of national accounting standards, tax rules, foreign aid explain the IFRS implementations across varying continents (Albu, Albu \& Alexander, 2014; Perera and Chand, 2015; Felski, 2015; Albu 
INTERNATIONAL JOURNAL OF ACADEMIC RESEARCH IN ACCOUNTING, FINANCE AND MANAGEMENT SCIENCES

Vol. 11, No. 1, 2021, E-ISSN: 2225-8329 ๑ 2021 HRMARS

et al., 2014; Lasmin, 2015; Kossentini and Othman, 2014). Notwithstanding, Ernest and Young, (2010) study revealed that some of the macroeconomic factors of IFRS adoption are weak in Africa. The study concluded that although South Africa had accounting reporting standards similar to IFRS, it faced difficulty in switching from local GAAP to the IFRS due to weak macroeconomic factors. Weaker standards have been attributed to differences in continental characteristics which unfortunately have received less attention from Africa literature perspectives. Contrary, the adoption of IFRS in African countries have experienced some delays due to the perception that some African countries have weak educational systems to augment the implementation the IFRS adoption and therefore, the adoption was not appropriate (Perera and Chand, 2015; Ernest and Young, 2010) in Africa.

Similarly, studies have examined the extent the financial market development factors explain IFRS adoption in African countries. It is undoubtedly true that the positive orientation of the capital market leads to share and encourage the stakeholders to understand and compare accounting and market information to make meaningful investment decisions. This would be a platform to acknowledge the effect of financial crises or risks and its influence on the macroeconomic factors. There is evidence that banks that adopted the IFRS reveal a lower rate of interest especially from the developing countries perspectives (Kim et al., 2011). Some IFRS empirical papers inherently evidence the quality accounting information for enhancing comparability, transparency, and understandability by stakeholders (Daske et al., 2008; Chritensen, 2012).

This paper is significant to policymakers, investors in Africa capital markets, financial market regulators, and researchers concerning the recognition of macroeconomic and financial market development factors within standards settings in the business environment. This study uses data from the 38 African countries over 2 years period of 2015-2016 and 2017-2018.

Our results evidence that the macroeconomic and financial market development factors have influenced the adoption of IFRS in African. This finding supports the decision usefulness theory that IFRS adoption decision depicts the economic outcome of matters that are on the financial accounts of interest to the users. Furthermore, the development of accounting settings emanate from the usefulness and quality of the macroeconomic decisions and quality financial sector orientations.

The other sections of this study are organized as follows. Section 2 reviews relevant existing literature in the subject areas. Section 3 focuses on research design which includes data, and estimation strategy. Section 4 describes estimation analysis and finally empirical discussion and conclusions are in section 5 ..

\section{Background, Literature Review, and Hypotheses Development Decision Usefulness Theory and IFRS}

This theory posits that final accounting numbers render little in making economic decisions by investors. This manner stifles investors' ability in assessing the financial health that determines the future strengths of the company. The adoption of IFRS enhances the relevance of financial information in comparing the fundamental acceptable basis to evaluate accounting numbers. This encourages fairness for higher accounting quality to facilitate usefulness of decision making (Funningham, 2010; Shima and Yang, 2012) thereby ameliorating the marketability of the share price of firms. 


\section{IFRS of African countries}

Touching on how a national set of financial accounting standards influences IFRS adoption, Jermakowicz and Epstein (2010) disclosed that the development of IFRS is an answer to countries looking for new financial reporting standards but do not have resources to do one. Therefore, countries without or weak national set of accounting standards are more ready to adopt IFRS than those with a full set of accounting standards and well better of (Johnson, 2011). DiMaggio and Powell (1983) based on Mimetic Isomorphism indicated that countries imitate after similar countries in standard settings. So, to avoid struggling and challenges in accounting standards development, some countries would comfortably adopt IFRS (Beneish et al., 2015 to ease themselves of any financial struggles.

Our results evidence that the macroeconomic and financial market development factors have an influence on the adoption of IFRS in African as far as strengthening institutions and ensuring sound resilient business environment are concerned (Huth et al., 2014; Brown and Tarca, 2012; Brown, 2011). This finding supports the decision usefulness theory that IFRS adoption decision depicts and supports economic outcome of matters that are on the financial accounts. Furthermore, development of accounting settings emanates from usefulness and quality of macroeconomic factors and quality financial sector orientations (Kapellas and Siougle, 2017; Tarca, 2012).

Contrary, we envisage the different route African countries implemented the IFRS compared to the developed countries' trend of footprint in the adoption. In this study, we focus on the extent by which the macroeconomic factors and financial market development factors play substantial orientations by explaining the switch to the IFRS in Africa. Stainbank (2014) disclosed in the study that sound market capitalization exhibits a faster-growing economy that tends to enhance adopting IFRS in Africa. This indicates in promoting transparency and quality in financial information (Assenso-Okofo et al., 2011).

\section{Macroeconomic factors and IFRS}

Macroeconomic factors explain the IFRS adoption and harmonization of accounting standards, even though there are adoption differences under the implementation of the new standards. North (2005) highlighted that such differences are fundamental for changing economic dynamics. So, it is believed that macroeconomic factors influence accounting measurement practices under its development systems (Nobes and Parker, 2010). Therefore, it is necessary to investigate the extent to which macroeconomic actors explain the adoption of IFRS in African settings.

Empirical studies on the macroeconomic factors and standard settings have proliferated over the last couple of years, due to importance of experience and knowledge, the level of professional accountants, familiarity with IFRS, the legal system, quality of national financial accounting standards, tax rules, and foreign aid, as influential macroeconomic determinants that encourage IFRS adoption globally (Albu, Albu, and Alexander, 2014; Perera and Chand, 2015; Felski, 2015; Perera and Chand, 2015; Albu et al., 2014; (Lasmin, 2015; Kossentini and Othman, 2014). Previous empirical research paid much attention to the legal system as a predominant force to reckon with among other factors (Doupnik and Slater, 1995; Bonito and Pais, 2018). Notwithstanding this assertion, Ernest and Young 
INTERNATIONAL JOURNAL OF ACADEMIC RESEARCH IN ACCOUNTING, FINANCE AND MANAGEMENT SCIENCES

Vol. 11, No. 1, 2021, E-ISSN: 2225-8329 @ 2021 HRMARS

(2010) emphasized that macroeconomic factors do not fully explain the African situation of IFRS implementations. This limitation partly explains why some African countries have not adopted the IFRS or otherwise.

Felski (2015) and, Kolsi and Zehri (2013) argued that because IFRS emanated from common law countries of the same legal systems, such nations are more likely to adopt IFRS than countries with code law. This assertion made the Anglo-Saxon colonized-nations in general demonstrating support for the full adoption of IFRS (Irvine, 2008).

In another stands, the adoption of IFRS is motivated more by social pressures of legitimacy than it is by economic reasoning as echoed by the isomorphism theory of DiMaggio and Powell (1983). Donor funds organization would expect nations to adopt the new standards that will provide quality returns for understandability, comparability, efficiency which in turn increase investor confidence and associated information quality. To qualify for such aid, donor countries put pressure on African nations to adopt the new standards for financial reports clarity. On a similar note, Kaya and Koch (2015) stipulated, that some-how the donor organizations influence IFRS applications in the larger extent. For example, the World Bank makes it mandatory for developing countries with membership of the IMF, World Bank Aid, and Britain Wood to embrace the adoption of IFRS. The World Bank is of the view that, by adopting the new standards, IFRS-adopters financial accounts with the World Bank would be well represented and understood by both parties with ease (Loeb and Zhu, 2012). By this, member-nations are attracted to adopt the new standards, as such move qualifies them to enjoy the loan facilities (Judge et al., 2010; Albu et al., 2011; Boolaky, 2012). Besides, Nobes and Parker (2010) cited that regulatory quality positively affects the possibility of IFRS adoption in developing countries. This is partly true where the regulatory quality creates a demand for competent and independent compliance and monitoring of accounting standards.

On the balance of the confirmatory discussion, the study, therefore, hypothesizes that macroeconomic quality factors are likely to influence the adoption of IFRS in the African continent.

\section{Financial market development and IFRS}

It is undoubtedly true that private sector firms' more or less shape the IFRS adoption and implementation, which in turn fortify the financial market development in African, especially in the common law nations. For the code law countries, the state and debt-holders drive the efficacy of accounting standards of accuracy of their debts, suggesting the relevance of financial markets operations under the new standards. A strong force of equity market in the common law countries enhance the IFRS adoption (Nobes, 2008), but some capital markets in Africa exhibit small and low equity markets, and therefore are evidencing IFRS implementation problems thereby disregarding the new standards adoption. This upholds the view that financial issues and strong earnings are critical to enhance the IFRS adoption in Africa. The soundness of financial sectors under the IFRS requires full disclosure on a timely basis for giving reasonable assurance of information quality which in turn provides quality investment decisions. 
INTERNATIONAL JOURNAL OF ACADEMIC RESEARCH IN ACCOUNTING, FINANCE AND MANAGEMENT SCIENCES

Vol. 11, No. 1, 2021, E-ISSN: 2225-8329 @ 2021 HRMARS

In a similar vein, Perera and Chand (2015) and Jemakowich (2006) argued that countries with a more developed capital market would adopt IFRS because of advantages of harmonization of financial statements to meet investors' expectations across national boundaries. Kossentini and Othman (2014) confirmed that the full IFRS adoption for listed firms is substantially associated with positive stock market development. Similarly, Daske (2006), and Zeghal and Mhedhbi (2006) affirmed a positive relationship between capital market and IFRS adoption. So, this paper hypothesizes that capital market development is likely to influence the adoption of IFRS in Africa. Previous research has suggested that financial market development triggers investment decisions and influences IFRS adoption (Bruggermann et al., 2012). This may imply that robust financial market development improves financial services processes, and offers affordability to enhance access to the capital market to give assurance of financial stability.

On this basis, the study hypothesis that a highly developed financial market is likely to cause the African countries to adopt IFRS.

\section{Data and Measurements}

This paper seeks to highlight the data collection source, the sample from the population, estimation of variables for measurement, descriptive statistics, and correlation analysis.

\section{Data}

This paper pooled macro-economic data from the global competiveness report of the World Bank Indicators (the data include: quality of accounting body, the legal system, quality of national financial accounting standards, the tax incentive for investors, foreign direct investment, domestic capital market, inflation and gross domestic product growth, and financial market development data (measured by availability of financial services, the affordability of financial services, financing through local equity market, ease of access to loans, venture capital market, soundness of banks, regulations of security exchange and legal right). We obtained the data from 38 African countries within the global competitiveness report for the period 2015-2016 and 2017-2018, utilizing the panel binary logistic regression model. The study used 38 African countries (IFRS adopters 21, Non-adopters 17).

\section{Measurement of estimation variables}

Table 1 tells us the derivations of both dependent and independent variables, and the sources of obtaining the data for this study. The IFRS serves as a dependent variable, which is dichotomous in that it is either adopted or not adopted by a country. Where a dependent variable serves as dichotomous outcome, no matter the nature of the data, it is suitable to use logistic regression (Gujarati, 2006). More importantly, the cross-sectional dimension (38 countries) of the data far exceeded the time dimension (2-year), making the study cross-sectional dimension biased.

Table 1 explains in details the variables employed in the study. 
INTERNATIONAL JOURNAL OF ACADEMIC RESEARCH IN ACCOUNTING, FINANCE AND MANAGEMENT SCIENCES

Vol. 11, No. 1, 2021, E-ISSN: 2225-8329 @ 2021 HRMARS

Table 1(a): definition and explanations of Variables

\begin{tabular}{|c|c|c|c|}
\hline Variable & $\begin{array}{l}\text { macroeconomic } \\
\text { Variable (s) }\end{array}$ & $\begin{array}{l}\text { Description/ } \\
\text { measurement }\end{array}$ & Source of data \\
\hline $\begin{array}{l}\text { Dependent } \\
\text { variable }\end{array}$ & $\begin{array}{l}\text { IFRS adoption } \\
\text { (IFRS) }\end{array}$ & $\begin{array}{l}\text { Whether the country has } \\
\text { adopted IFRS (coded as } \\
\text { 1) and if not (coded as } \\
\text { 0). }\end{array}$ & $\begin{array}{l}\text { International } \\
\text { Accounting } \\
\text { Standards Board }\end{array}$ \\
\hline \multicolumn{4}{|l|}{ Ind. Variable } \\
\hline QAB & $\begin{array}{l}\text { Quality of } \\
\text { accounting body } \\
\text { for country }\end{array}$ & $\begin{array}{l}\text { Tertiary education } \\
\text { degree in accounting } \\
\text { enrollment rate. }\end{array}$ & $\begin{array}{l}\text { Global } \\
\text { Competitiveness } \\
\text { Reports (GCR) }\end{array}$ \\
\hline LGS & Legal system & $\begin{array}{l}\text { A country with common } \\
\text { law (coded as } 1 \text { ) and } \\
\text { code law (coded as } 0 \text { ) }\end{array}$ & GCR \\
\hline NAS & $\begin{array}{l}\text { National } \\
\text { accounting } \\
\text { system quality }\end{array}$ & $\begin{array}{l}\text { Country uses national } \\
\text { accounting standards }\end{array}$ & GCR \\
\hline TIL & Tax rate & Total tax rate & GCR \\
\hline FDI & $\begin{array}{l}\text { Foreign direct } \\
\text { investment }\end{array}$ & $\begin{array}{l}\text { Foreign direct } \\
\text { investment and } \\
\text { technology transfer }\end{array}$ & GCR \\
\hline DCM & $\begin{array}{l}\text { Domestic capital } \\
\text { market dev't }\end{array}$ & $\begin{array}{l}\text { National capital market } \\
\text { attractiveness }\end{array}$ & GCR \\
\hline INF & Inflation & $\begin{array}{l}\text { Annual percentage } \\
\text { change }\end{array}$ & GCR \\
\hline GDP & $\begin{array}{l}\text { Gross domestic } \\
\text { product }\end{array}$ & $\begin{array}{l}\text { Purchasing power parity } \\
\$ \text { billion }\end{array}$ & GCR \\
\hline
\end{tabular}

\begin{tabular}{|c|c|c|c|}
\hline \multicolumn{3}{|c|}{ Table 1 (b): Descriptions of Variables } & \multirow[b]{2}{*}{ Source of data } \\
\hline Variable & $\begin{array}{l}\text { Financial market } \\
\text { development }\end{array}$ & $\begin{array}{l}\text { Explanations of } \\
\text { measurements }\end{array}$ & \\
\hline AFS & $\begin{array}{l}\text { Availability of } \\
\text { financial services }\end{array}$ & $\begin{array}{l}\text { financial sector products } \\
\text { and services for meeting } \\
\text { businesses needs }\end{array}$ & GCR \\
\hline AFFS & $\begin{array}{l}\text { Affordability of } \\
\text { financial services }\end{array}$ & $\begin{array}{l}\text { financial services costs } \\
\text { inhibit businesses tasks }\end{array}$ & GCR \\
\hline FLEM & $\begin{array}{l}\text { Financing through } \\
\text { local equity } \\
\text { market }\end{array}$ & $\begin{array}{l}\text { issuing share on capital } \\
\text { market to finance }\end{array}$ & GCR \\
\hline EAL & $\begin{array}{l}\text { Ease of access of } \\
\text { loan }\end{array}$ & $\begin{array}{l}\text { businesses obtaining } \\
\text { loans from banks }\end{array}$ & GCR \\
\hline
\end{tabular}


INTERNATIONAL JOURNAL OF ACADEMIC RESEARCH IN ACCOUNTING, FINANCE AND MANAGEMENT SCIENCES

Vol. 11, No. 1, 2021, E-ISSN: 2225-8329 @ 2021 HRMARS

\begin{tabular}{|l|l|l|l|}
\hline VCM & $\begin{array}{l}\text { Venture capital } \\
\text { market }\end{array}$ & $\begin{array}{l}\text { Start-up entrepreneurs } \\
\text { for equity funding of } \\
\text { risky project }\end{array}$ & GCR \\
\hline SBK & $\begin{array}{l}\text { Soundness of } \\
\text { banks }\end{array}$ & $\begin{array}{l}\text { Businesses perception on } \\
\text { soundness of banks }\end{array}$ & GCR \\
\hline RSE & $\begin{array}{l}\text { Regulation of } \\
\text { securities } \\
\text { exchange }\end{array}$ & $\begin{array}{l}\text { Extent to which } \\
\text { regulators ensure } \\
\text { stability of financial } \\
\text { market }\end{array}$ & GCR \\
\hline LRI & Legal right index & $\begin{array}{l}\text { Degree of borrowers and } \\
\text { lenders right }\end{array}$ & GCR \\
\hline
\end{tabular}

\section{Empirical Method and Analysis}

This section addresses the model specification and the unit of analysis of results.

\section{Model specifications}

The purpose of the study is under the premise of the macroeconomic and financial market development factors on the IFRS adoption, bearing in mind other control variables in line with Kaya and Kosh (2015), Lasmin (2011), and Zehri and Chouaibi (2013) accepted the logistic regression accordingly. Thus, the probability that a particular African country had adopted IFRS for this specification:

$$
P_{i}=\operatorname{Pr}\left(y_{i}=1\right)=\frac{e^{X \beta}}{1+e^{X \beta}}
$$

Conversely, the probability that a particular African country has not adopted IFRS is also expressed as:

$$
\left(1-P_{i}\right)=\operatorname{Pr}\left(y_{i}=0\right)=\frac{1}{1+e^{X \beta}}
$$

Thus, the odds ratio is the ratio of the probability that an African country has adopted IFRS to the probability that an African country has not adopted, written as:

$$
\frac{P_{i}}{1-P_{i}}=\frac{1+e^{X \beta}}{1+e^{-X \beta}}
$$

The logarithm of the ratio $P_{i}$ and $\left(1-P_{i}\right)$ is the log-odds ratio and the log-odds ratio is a non-linear function of the explanatory variables. That is:

$$
\log \frac{P_{i}}{1-P_{i}}=\beta_{0}+\sum_{j=1}^{k} \beta_{j} x_{i j}
$$

Based on the binary logistic model, this study specifies the model for estimating general macroeconomic factors that influence IFRS adoption of African countries as shown in equation 1 . The Table 1a explains the variables employed: 
INTERNATIONAL JOURNAL OF ACADEMIC RESEARCH IN ACCOUNTING, FINANCE AND MANAGEMENT SCIENCES

Vol. 11, No. 1, 2021, E-ISSN: 2225-8329 @ 2021 HRMARS

$$
\begin{gathered}
\operatorname{IFRS}_{i, t}=\propto_{0}+\propto_{1} Q A B_{i, t}+\propto_{2} L S_{i, t}+\propto_{3} N A S_{i, t}+\propto_{4} F D I_{i, t}+\propto_{5} D C M_{i, t}+\propto_{6} T I L_{i, t}+\propto_{7} I N F_{i, t} \\
+\propto_{8} G D P_{i, t}+\epsilon_{i, t} \ldots \ldots \ldots \ldots \ldots .1
\end{gathered}
$$

Equation 2 explains the model estimation of objective two of this study that states the extent to which the financial market development factors influence the IFRS adoption of African countries.

$$
\begin{gathered}
\operatorname{IFRS}_{i, t}=\propto_{0}+\propto_{1} \operatorname{AVFS}_{i, t}+\propto_{2} \text { AFFS }_{i, t}+\propto_{3} \text { FTLEM }_{i, t}+\propto_{4} \text { EAL }_{i, t}+\propto_{5} \text { VCM }_{i, t}+\propto_{6} S B K_{i, t} \\
+\propto_{7} \operatorname{RSE}_{i, t}+\propto_{8} \operatorname{LRI}_{i, t}+\epsilon_{i, t} \ldots \ldots \ldots \ldots \ldots \ldots .2
\end{gathered}
$$

\section{Summary Statistics and Correlation Analysis}

Descriptive statistics: Macroeconomic factors

Table 2 shows the descriptive statistics of the variables employed for the study. Panel A of Table 2 shows the descriptive in variations forms of the macroeconomic factors. Mean (standard error) value of quality of accounting body measured as tertiary education enrollment rate shows 11.44 (1.18) at a range within $95 \%$ confidence interval. The means (standard error) of a common legal system of 0.53 $(0.06)$ is more than African countries with Code legal systems.

Panel A Table 2: Summary statistics: macroeconomic factors

\begin{tabular}{lllll}
\hline Variables & Mean & Std. Err & \multicolumn{2}{l}{ 95\% Conf. Interval } \\
\hline Quality of accounting body (QAB) & 11.435 & 1.179 & 9.085 & 13.785 \\
Legal system (LGS) & 0.533 & 0.058 & 0.418 & 0.649 \\
National accounting system quality(NAS) & 0.747 & 0.050 & 0.645 & 0.847 \\
Foreign direct investment (FDI) & 3.848 & 0.086 & 3.676 & 4.020 \\
Domestic capital market (DCM) & 2.867 & 0.118 & 2.631 & 3.102 \\
Tax incentive for investors (TIL) & 3.523 & 0.066 & 3.390 & 3.655 \\
Inflation (INF) & 5.788 & 0.666 & 4.460 & 7.116 \\
Gross domestic product (GDP) & 3.659 & 0.182 & 3.297 & 4.021 \\
\hline
\end{tabular}

Panel A of Table 2 depicts a mean (standard error) of 0.75 (3.85) the for foreign direct flows, so as mean values of the domestic capital market and tax incentive for investors show $0.75(0.05)$ and 3.85 (0.09) respectively. Inflation and gross domestic product have some mean values of 5.788 and 3.659 respectively. It is $95 \%$ certainty that the inflation rate and gross domestic product growth in African countries are within the range of 3.30 and 7.116. Panel B of Table 2 presents variation scores of the macroeconomic variables within and across countries. It shows that standard deviation values between countries exceed the standard deviation values within countries. The legal system within the country does not vary, suggesting that a country with a common law or code law system has minimal influence of the switched. Gross domestic product varied more with countries than across countries, an indication that growth paths of African countries have not been smooth given the frequent growth fluctuations exhibits. 
INTERNATIONAL JOURNAL OF ACADEMIC RESEARCH IN ACCOUNTING, FINANCE AND MANAGEMENT SCIENCES

Vol. 11, No. 1, 2021, E-ISSN: 2225-8329 @ 2021 HRMARS

Panel B Table 2: Variation of macroeconomic factors within and across countries

\begin{tabular}{lllll}
\hline Variables & Std. dev Btn & Std. dev. Within & Min. & Max. \\
\hline QAB & 10.023 & 2.041 & 0 & 41.2 \\
LS & 0.506 & 0 & 0 & 1 \\
NAS & 0.431 & 0.082 & 0 & 1 \\
FDI & 0.687 & 0.300 & 2.2 & 4.9 \\
DCM & 1.022 & 0.046 & 1 & 5.1 \\
TIL & 0.555 & 0.170 & 2.3 & 5.3 \\
INF & 5.767 & 1.931 & -1.8 & 23.8 \\
GDP & 1.563 & 1.990 & 0.875 & 7.032 \\
\hline
\end{tabular}

Descriptive statistics- Financial Market Development

This study also examines the financial market development impact on IFRS adoption in African countries. Table 3 shows descriptive statistics of the financial market development variables.

Table 3: Descriptive statistics

\begin{tabular}{llllll}
\hline Variables & & Mean & Std. dev & Min. & Max. \\
\hline Availability of financial & Overall & 3.707 & 0.748 & 1.9 & 6.1 \\
services (AFS) & Between & & 0.693 & 2.3 & 5.55 \\
& Within & & 0.292 & 2.607 & 4.807 \\
Affordability of financial & Overall & 3.409 & 0.643 & 2 & 5.3 \\
services (AFFS) & Between & & 0.558 & 2.3 & 4.7 \\
& Within & & 0.329 & 2.709 & 4.109 \\
Financing through local & Overall & 3.3 & 0.724 & 1.6 & 5.6 \\
equity market (FLEM) & Between & & 0.667 & 2.1 & 5.1 \\
& Within & & 0.302 & 1.8 & 4.8 \\
Ease of access to loans & Overall & 2.917 & 0.689 & 1.5 & 5.4 \\
(EAL) & Between & & 0.501 & 2.05 & 3.9 \\
& Within & & 0.473 & 1.417 & 4.417 \\
Venture capital market & Overall & 2.473 & 0.409 & 1.5 & 3.4 \\
(VCM) & Between & & 0.368 & 1.63 & 3.3 \\
& Within & & 0.180 & 1.923 & 3.023 \\
Soundness of banks & Overall & 4.275 & 0.851 & 2 & 6.4 \\
(SBK) & Between & & 0.825 & 2.4 & 5.95 \\
& Within & & 0.262 & 3.375 & 5.175 \\
Regulation of security & Overall & 3.844 & 0.779 & 1.9 & 6.1 \\
exchange (RSE) & Between & & 0.706 & 2.25 & 5.45 \\
& Within & & 0.335 & 2.294 & 5.394 \\
Legal right index (LRI) & Overall & 4.867 & 2.219 & 1 & 11 \\
& Between & & 2.126 & 1 & 11 \\
& Within & & 0.652 & 2.367 & 7.367 \\
\hline & & & & &
\end{tabular}


INTERNATIONAL JOURNAL OF ACADEMIC RESEARCH IN ACCOUNTING, FINANCE AND MANAGEMENT SCIENCES

Vol. 11, No. 1, 2021, E-ISSN: 2225-8329 @ 2021 HRMARS

Table 4 shows that standard deviation scores of all the financial market development variables varied more across African countries, except the legal right index. This shows that African countries are widely different in terms of financial market development. The legal right index varied more within countries than across the African countries.

\section{Correlation Matrix}

Pearson's correlation matrix (Panel A Table 4) among macroeconomic variables is a positive correlation with IFRS adoption. The low adoption of IFRS in African countries is attributed to an improved quality of accounting body and a fall in the quality of the accounting body quality increases the likelihood of adopting IFRS in African countries. Table 4 shows that the correlations are both positive and negative to range from 0.111 to 0.653 and, from -0.065 to -0.196 respectively.

Pearson correlation matrix presented in Panel B of Table 4 indicates that financial market development factors do not show any correlations. This is because no coefficients are greater than 0.7 ( $r$ for all $<0.7$ ), suggesting that there is no problem of multicollinearity present in the data set. The venture capital market (VCM) exhibits a weak negative correlation with IFRS adoption in African countries.

Panel A Table 4: Correlation matrix: macroeconomic factors and IFRS

\begin{tabular}{llllllllll}
\hline & IFRS & QAB & LGS & NAS & FDI & DCM & TIL & INF & GDP \\
\hline IFRS & 1.000 & & & & & & & & \\
QAB & -0.065 & 1.000 & & & & & & & \\
LGS & 0.598 & -0.172 & 1.000 & & & & & & \\
NAS & 0.209 & 0.205 & - & 1.000 & & & & & \\
FDI & 0.653 & -0.196 & 0.298 & 0.248 & 1.000 & & & & \\
DCM & 0.144 & 0.372 & - & 0.575 & 0.086 & 1.000 & & & \\
TIL & 0.331 & 0.414 & 0.332 & 0.168 & 0.303 & 0.088 & 1.000 & & \\
INF & 0.251 & -0.174 & 0.241 & 0.126 & 0.060 & 0.174 & 0.032 & 1.000 & \\
GDP & 0.111 & 0.358 & - & 0.571 & 0.092 & 0.484 & 0.068 & 0.162 & 1.000 \\
\hline
\end{tabular}


INTERNATIONAL JOURNAL OF ACADEMIC RESEARCH IN ACCOUNTING, FINANCE AND MANAGEMENT SCIENCES

Vol. 11, No. 1, 2021, E-ISSN: 2225-8329 @ 2021 HRMARS

Panel B Table 4 Correlation matrix: financial market development and IFRS

\begin{tabular}{|c|c|c|c|c|c|c|c|c|c|}
\hline & IFRS & AFS & AFFS & FLEM & EAL & VCM & SBK & RSE & LRI \\
\hline IFRS & 1.000 & & & & & & & & \\
\hline AVS & 0.455 & 1.000 & & & & & & & \\
\hline AFFS & 0.311 & 0.573 & 1.000 & & & & & & \\
\hline FLEM & 0.316 & 0.429 & 0.605 & 1.000 & & & & & \\
\hline EAL & 0.101 & 0.558 & 0.404 & 0.568 & 1.000 & & & & \\
\hline VCM & $\begin{array}{l}- \\
0.053\end{array}$ & 0.522 & 0.568 & 0.547 & 0.709 & 1.000 & & & \\
\hline SBK & 0.252 & 0.609 & 0.569 & 0.625 & 0.525 & 0.513 & 1.000 & & \\
\hline RSE & 0.484 & 0.608 & 0.661 & 0.567 & 0.567 & 0.469 & 0.689 & 1.000 & \\
\hline LRI & 0.285 & 0.235 & 0.133 & 0.243 & 0.214 & 0.108 & 0.161 & 0.269 & 1.000 \\
\hline
\end{tabular}

\section{Analysis of Regression Results}

This paper focused on the macroeconomic and financial market development factors' effects on the IFRS adoption of African countries. Using the panel binary logistic regressions, the paper reported on both odd ratios and the marginal effect of the results. This study demonstrated that the common law positively impacts IFRS adoption, showing an odd ratio value of 4094.54, indicating a higher likelihood of adopting IFRS than the code law countries. This finding is consistent with Kolsi and Zehri (2013) and Ben Salem et al. (2017). On the relationship between countries with weak national accounting standards and IFRS adoption, this paper demonstrated a higher odd ratio value of 664.68, indicating a strong aversion to adopting new quality standards, confirming Jermakowics and Epstein's (2010) findings. Generally, most African countries do not possess acumen skills for the development of quality standards, having obsolete accounting standards. This therefore necessitates the majority of them to embrace the IFRS adoption (World Bank, 2004). 
INTERNATIONAL JOURNAL OF ACADEMIC RESEARCH IN ACCOUNTING, FINANCE AND MANAGEMENT SCIENCES

Vol. 11, No. 1, 2021, E-ISSN: 2225-8329 @ 2021 HRMARS

Table 5: Logistic regression results: General macroeconomic factors and IFRS Adoption in Africa

\begin{tabular}{|c|c|c|c|c|c|c|c|}
\hline Variables & $D y / d x$ & Odds ratio & Std. err & Z & p-value & \multicolumn{2}{|c|}{ 95\% Conf. Interval } \\
\hline QAB & 0.009 & 1.162 & 0.119 & 1.47 & 0.140 & 0.951 & 1.423 \\
\hline LGS & 0.468 & 4094.542 & 13349.08 & 2.55 & 0.011 & 6.872 & 2439514 \\
\hline NAS & 0.366 & 664.682 & 2093.603 & 2.06 & 0.039 & 1.377 & 320828.7 \\
\hline FDI & 0.366 & 1175.042 & 3155.619 & 2.63 & 0.008 & 6.083 & 226979.5 \\
\hline DCM & 0.942 & $1.82 \mathrm{e}+07$ & $1.40 \mathrm{e}+08$ & 2.18 & 0.030 & 5.249 & $6.33 e+13$ \\
\hline TIL & -0.068 & 0.297 & 0.393 & -0.92 & 0.359 & 0.022 & 3.962721 \\
\hline INF & 0.007 & 1.130 & 0.118 & 1.17 & 0.242 & 0.921 & 1.388181 \\
\hline GDP & 0.649 & $9.89 e-07$ & 0.00005 & 2.19 & 0.029 & $3.25 e-10$ & 0.3008 \\
\hline Constant & & $4.16 \mathrm{e}-18$ & $6.26 \mathrm{e}-17$ & -2.66 & 0.008 & $6.65 e-31$ & 0.000026 \\
\hline $\begin{array}{l}\mathrm{N} \\
\text { LR Ch }(8) \\
\text { prob>chi } \\
\text { Pseudo } \mathrm{R}^{2} \\
\text { Log } \\
\text { likelihood }\end{array}$ & & $\begin{array}{l}76 \\
77.17 \\
0.000 \\
0.7470 \\
-13.07158\end{array}$ & & & & & \\
\hline
\end{tabular}

There are higher odds ratio values for foreign direct investment (1175), capital market development (1.80e), and gross domestic product (9.98e-06) of adopting IFRS, compared with countries with lower odd ratio values. Studies on foreign direct investment and IFRS adoption have shown positive relationships among the developing countries (Phuong and Nguyen, 2012; Akpome and Nnadi, 2017). This presupposes that African countries with huge fixed direct investment flows adopt the IFRS, compared to countries with less fixed direct investment inflows. It is also the belief that the attractiveness of capital markets of Africa tends to put pressure on African governments to adopt IFRS to facilitate comparability and transparency of financial information (Jermakowich and Tomaszewski, 2006; Prochazka and Pelak, 2015; and Kossentini and Othman 2014). Furthermore, it is evidenced that an increase in fixed investment and capital market development causes growth in the GDP within countries (Felski, 2015; Judge et al., 2010). The marginal effect results revealed a higher likelihood of adopting IFRS for the FDI, capital market development, and the GDP by 0.366, 0.942 , and 0.649 respectively (see Table 5). Contrary, the tax rate, inflation rate, and quality of the accounting body are not influenced by the likelihood of the IFRS adoption in the African countries. Again it is found that the macroeconomic factors accounted for $74.7 \%$ of the variation in the IFRS adoption of African countries.

Table 6 shows that African countries of developed financial services have a higher likelihood ratio of 38.895 at $1 \%$ significantly to switch to the IFRS. These findings support prior extant studies, that the availability of financial service exhibits a better likelihood of IFRS adoption (Bruggermann et al., 2012) by nations. Also, further empirical results show that African nations of developed venture capital markets, strong soundness of banking activities, and effective regulation of security exchange benefit form a higher likelihood of adopting IFRS comparatively. Generally, the results evidenced an odd ratio values of $0.020,0.061$ and, 44.41 for venture capital market, soundness of banks, and regulation of security exchange benefit respectively, that is indicating a higher likelihood of adopting IFRS. These 
INTERNATIONAL JOURNAL OF ACADEMIC RESEARCH IN ACCOUNTING, FINANCE AND MANAGEMENT SCIENCES

Vol. 11, No. 1, 2021, E-ISSN: 2225-8329 @ 2021 HRMARS

findings suggest that IFRS-adopting African countries are heavily depended on financial market development activities.

Table 6: Logistic regression results -Financial market development and IFRS adoption in Africa

\begin{tabular}{|c|c|c|c|c|c|c|c|}
\hline Variables & $\mathrm{Dy} / \mathrm{dx}$ & Odds ratio & Std.err & Z & p-value & \multicolumn{2}{|c|}{ 95\% Conf. Interval } \\
\hline AFS & 0.009 & 38.895 & 58.499 & 2.43 & 0.015 & 2.040 & 741.527 \\
\hline AFFS & 0.059 & 1.713 & 2.614 & 0.35 & 0.724 & 0.086 & 34.089 \\
\hline FLEM & -0.044 & 0.668 & 0.807 & -0.33 & 0.738 & 0.063 & 7.128 \\
\hline $\mathrm{EAL}$ & -0.135 & 0.289 & 0.279 & -1.29 & 0.199 & 0.044 & 1.919 \\
\hline VCM & 0.425 & 0.020 & 0.037 & 2.15 & 0.031 & 0.0058 & 0.7029 \\
\hline SBK & 0.306 & 0.061 & 0.069 & 2.47 & 0.014 & 0.007 & 0.560 \\
\hline RSE & 0.413 & 44.410 & 63.054 & 2.67 & 0.008 & 2.748 & 717.818 \\
\hline LRI & 0.025 & 1.255 & 0.223 & 1.28 & 0.201 & 0.886 & 1.779 \\
\hline Constant & & 0.020 & 0.0637 & -1.23 & 0.219 & 0.0004 & 10.213 \\
\hline Number of obs. & 76 & & & & & & \\
\hline $\mathrm{LR} \mathrm{Ch}^{2}(8)$ & 51.26 & & & & & & \\
\hline Prob $>\mathrm{chi}^{2}$ & & & & & & & \\
\hline Pseudo $\mathrm{R}^{2}$ & 0.000 & & & & & & \\
\hline Log likelihood & 0.4962 & & & & & & \\
\hline & -26.028 & & & & & & \\
\hline
\end{tabular}

Overall, a unit increase in the venture capital market, soundness of banks, and regulation of security exchange reveal values $0.425,0.306$, and 0.413 . The main conclusion is that the financial market development factors exhibit a strong association with the adoption of IFRS in African countries at both $1 \%$ and $5 \%$ statistical levels. The following variables: financing through the local equity market, legal right index, and access to loans results achieved a negative impact on the adoption of IFRS in the African continent

\section{Discussion and Conclusions}

The literature on IFRS adoption concerning financial sector development and the IFRS in the African continent has been scanty, but much research is done with the macroeconomic factors, even though financial sector development does not matter. Decision usefulness theory is applied to underpin this study in examining the relationship between the IFRS of accounting numbers and macroeconomic and financial markets determinants. The study employed both theoretical and empirical literature to establish the hypotheses to position the objectives of the study. The study used a sample of 38 African countries (20 IFRS adopters, 18 non-adopters). The logistic regression estimation model is employed, with data from the Global Competitiveness Report of the World Economic Forum (WEF) of the World Development Indicators.

The paper, therefore, concludes that the quality of national accounting standards influence the adoption of IFRS and that common law countries adopt IFRS easily, compared to the coded law nations. In a similar vein, the FDI inflows, the domestic capital market development, the GDP size, and determinants of financial market development affirmatively influence IFRS adoption in African 
INTERNATIONAL JOURNAL OF ACADEMIC RESEARCH IN ACCOUNTING, FINANCE AND MANAGEMENT SCIENCES

Vol. 11, No. 1, 2021, E-ISSN: 2225-8329 @ 2021 HRMARS

countries in minimal ways. This has critical implications for non-adopters of IFRS to put measures in place to switch to the new standards, in compliance with the global accounting standards pathway. Another revealing outcome is the fact that some macroeconomic factors exhibited positive significance on the IFRS, amid skeptical opinion that institutional quality is more or less compromised in Africa. The empirical findings also suggest that the financial market development of Africa is critical and consistently exhibiting significant impact on the IFRS adoption. Indeed, this finding is not surprising considering the more or less resilient bank-oriented economy of African countries, and the more resources deployed into the financial environment. These findings are cautiously not to be generalized to other emerging economies due to differences in both financial market operations and macroeconomic factors (Orlova, 2020; Wang and Esqueda, 2014).

The study recommends that standard-setters ought to assist non-adopters in Africa by assessing their current situations in supporting to switch for IFRS adoption. Our results are encouraging the stakeholders of IFRS to corroborate with the government to render assistance on training and education that promotes the adoption of IFRS. Our results assert that sound macroeconomic fundamentals like developed capital markets drive economic growth with the subsequent attraction of more foreign investors, and more foreign direct inflows thereby enhancing the adoption of IFRS in African countries. Because of the outcome of the results and considering the economic benefits of adopters, policymakers should off-lead their attention and policies to invest more in the standards settings as well as providing subsidized and quality education to help the non-adopters. We envisage a more enriching study of the data that considers comparative Asian economies on the topic.

\section{References}

Albu, C., Albu, N., \& Alexander, D. (2014). When global accounting standards meet the local context - Insights from an emerging economy. Critical Perspectives on Accounting, 25(6), 489- 510.

Albu, N., Albu, C. N., \& Filip, A. (2017). Corporate reporting in Central and Eastern Europe: Issues, challenges and research opportunities. Accounting in Europe, 14(3), 249-260.

Amihud, Y. \& Mendelson, H. (1986). Asset Pricing and the Bid-Ask Spread. Journal of Financial Economics, 17: 223-249.

Akpomi M. E., and Nnadi, M. A. (2017) The impact of International Financial Reporting Standards (IFRS) adoption on Foreign Direct Investments (FDI): Evidence from Africa and implications for managers of education, Journal of Accounting and Financial Management, Vol. 3, Issue 2, pp. 51-65

Assenso-OKOFO, O., Ali, M. J., and Ahmed, K. (2011), 'The development of accounting and reporting in Ghana', The International Journal of Accounting, Vol. 46, No. 4, pp.459-480

Ball, R. (2016), 'IFRS- ten years after' Accounting and Business Research, Vol. 46, No. 5, pp.545-571

Barth, M. E., Landsman, W. R., \& Lang, M. H. (2008). International Accounting Standards and Accounting Quality. Journal of Accounting Research

Beaver, W. H., Correia, M., and McNichols, M. F. (2010) Financial Statement analysis and the prediction of financial distress, Foundation and Trends in Accounting, 5, 99-173

Beneish, M. D., Miller, B. P., \& Lombardi Yohn, T. (2015). Macroeconomic evidence on the impact of mandatory IFRS adoption on equity and debt markets. Journal of Accounting and Public Policy, 34(1), 1-27. 
INTERNATIONAL JOURNAL OF ACADEMIC RESEARCH IN ACCOUNTING, FINANCE AND

MANAGEMENT SCIENCES

Vol. 11, No. 1, 2021, E-ISSN: 2225-8329 @ 2021 HRMARS

Ben Salem, R., Salma, D. A., and Saihi, M. (2017), Determinants of full IFRS adoption, International Journal Managerial and Financial Accounting, Vol. 9, No. 2.

Brown, P. (2011). International Financial Reporting Standards: What are the benefits? Accounting and Business Research, 41, 269-285.

Brown, P. (2013). Some observations on research on the benefits of nations of adopting IFRS. The Japanese Accounting Review, 3, 1-19.

Brown, P., \& Tarca, A. (2012). Ten years of IFRS: Practitioners' comments and suggestions for research. Australian Accounting Review, 22(4), 319-330.

Boolaky, P. K. (2012). Accounting development and international financial reporting standards in small island economies: The case of Mauritius between 1960 and 2008. Journal of Accounting in Emerging Economies, 2 (1), 4-29

Bonito, A., \& Pais, C. (2018), The macroeconomics determinants on the adoption of the IFRS for SMEs. Spanish Accounting Review, 21(2), 116-127

Brüggemann, U., Daske, H., Homburg, C., Pope, P. F. (2012). How do Individual Investors React to Global IFRS Adoption? SSRN Electronic Journal.

Daske, H. (2006). Economic benefits of adopting IFRS or US-GAAP-Have the expected cost of equity capital really decreased?. Journal of Business Finance and Accounting, 33(3-4): 329-373.

DiMaggio, P. J., Powell, W. W. (1983). The Iron Cage Revisited: Institutional Isomorphism and Collective Rationality in Organizational Fields. American Sociological Review, 147-160.

Doupnik, T., \& Slater, S. (1995). External environment, culture and accounting practice: A preliminary test of a general model of international accounting development. International Journal of Accounting, 30, 189-207.

Duarte, A. M. P., Saur-Amaral, I., \& Azevedo, G. M. C. (2015). IFRS Adoption and Accounting Quality: A Review. Journal of Business \& Economic Policy Vol. 2, No. 2; June 2015. 104-123

Elliot, B., \& Elliot, J. (2013). Financial accounting and reporting. Harlow: Pearson Education, Inc.

Ernest, M., \& Young, R. (2010). IFRS readiness amongst South African companies - a survey.

Felski, E. (2015). Do common features exist among countries that locally adopt IFRS? International Journal of Accounting and Financial Reporting, 5(2), 144-177.

Gujarati, D. N. (2006), Essentials of Econometrics, 3rd ed., McGraw-Hill, Irwin.

Irvine, H. (2008). The global institutionalization of financial reporting: The case of the United Arab Emirates. Accounting Forum, 32(2), 125-142.

Johnson, D. (2011). Political systems, lobbying, and the adoption of International Financial Reporting Standards. Working paper, Sloan School of Management Massachusetts, Cambridge, MA.

Jermakowicz, E., \& Gornik-Tomaszewski, S. (2006). Implementing IFRS from the perspective of EU publicly traded companies. Journal of International Accounting, Auditing and Taxation, 15(2), 170-196.

Jermakowicz, E., \& Epstein, B. (2010). IFRS for SMEs - An option for U.S. private entities? Review of Business, 30(2), 72-79.

Judge, W., Li, S., \& Pinsker, R. (2010). National adoption of international accounting standards: An institutional perspective. Corporate Governance: An International Review, 18(3), 161-174.

Kapellas, K., and Siougle, G. (2018). The Effect of IFRS Adoption on Investment Management:A Review of the Literature, Technology and INVESTMENT, Vol. 9, pp. 1-23 
INTERNATIONAL JOURNAL OF ACADEMIC RESEARCH IN ACCOUNTING, FINANCE AND

MANAGEMENT SCIENCES

Vol. 11, No. 1, 2021, E-ISSN: 2225-8329 @ 2021 HRMARS

Kaya, D., \& Koch, M. (2015). Countries adoption of the international financial reporting standard for small and medium-sized entities (IFRS for SMEs) - Early empirical evidence. Accounting and Business Research, 45(1), 93-120.

Kim, J., Tsui, J. and Yi, H. (2011), 'The voluntary adoption of international financial reporting standards and loan contracting around the world'. Review of Accounting Studies, Vol. 17, No. 3, pp. 474-517

Kolsi, M., \& Zehri, F. (2013). The determinants of IAS / IFRS adoption by emergent countries. Working paper, Emirates College of Technology, Abu Dhabi.

Kossentini, A., \& Othman, H. (2014). A study of the institutional and economic determinants of IFRS adoption in emerging economies. Working paper, University of Tunis, Tunis.

Lasmin, R. (2011). An institutional perspective on international financial reporting standards adoption in developing countries. Academy of Accounting and Financial Studies Journal, 15(2), 61-71.

Lawrence, A. (2013). Individual investors and financial disclosure, Journal of Accounting and Economics, 56(1), 130-147

Nnadi, M. and Soobaroyen, T. (2015), 'International financial reporting standards and foreign direct investment: the case of Africa' Advances in Accounting, Vol.31 No. 2, pp.228-238

North, D. C. (2005), Understanding the Process of Economic Change, Princeton University Press, New Jersey.

Norbes, C., \& Parker, R. (2010). Comparative International Accounting. Prentice Hall, 2004.

Orlova, S. V. (2020), Cultural and macroeconomic determinants of cash holdings management, Wiley, DOi:10.111/jifmr2121

Perera, D., \& Chand, P. (2015). Issues in the adoption of international financial reporting standards (IFRS) for small and medium-sized enterprises (SMEs). Advances in Accounting, 31(1), 165178.

Prochazka, D., and Pelak, J. (2015). The development of Capital Markets in the IFRS Era, Procedia Economics and Finance, Vol.25, pp.116-126

Rahman, A., Perera, H., \& Siva, G. (2013): Accounting Practice Harmony, accounting regulation and firm characteristics, Abacus, 1, 46-77.

ROSC. (2004). Report on Country Observations of Standards and Codes (ROSC) 2000-2007. Washington D.C.: International Bank for Reconstruction and Development/ World Bank

Stainbank, J. (2014), 'Factors influencing the adoption of international financial reporting standards by Africa countries', South African Journal of Accounting Research, Vol. 28, No. 1, pp. 79-95

World Bank. (2004).Report on Country Observations of Standards and Codes (ROSC) 2000-2007. Washington D.C.: International Bank for Reconstruction and Development/ World Bank.

Wang, D., \& Esqueda, O. (2014). National cultural effects on leverage decisions: Evidence from emerging-market ADRs. Research in International Business and Finance, 31, 152-177.

Zeghal, D., Mhedhbi, K. (2006). An analysis of the factors affecting the adoption of international accounting standards by developing countries. The International Journal of Accounting, 41, 373-386. 
INTERNATIONAL JOURNAL OF ACADEMIC RESEARCH IN ACCOUNTING, FINANCE AND MANAGEMENT SCIENCES

Vol. 11 , No. 1, 2021, E-ISSN: 2225-8329 @ 2021 HRMARS

Appendix 1: Adopters and Non-adopters of IFRS

Table1: Study Population: IFRS adopters and Non-IFRS Adopters

IFRS adopters Non-IFRS adopter

Ghana, Nigeria, South Africa, Sierra Leone, Kenya, Zimbabwe, Tunisia, Namibia, Botswana, Libya, Lesotho, Malawi, Mauritius, Morocco, Mozambique Swaziland, Tanzania, Uganda, Rwanda, Zambia,
Algeria, Angola, Cameroom, Chad, Cote D'Ivoire, Democratic Republic of Congo, Egypt, Equatorial Guinea, Gabon, Guinea Conakry, Democratic Republic of Congo, Senegal, Ethiopia, Madagascar, Mauritania, Seychelles 